\title{
STRATEGI PENGEMBANGAN AGROINDUSTRI TAHU CAHAYA DI DUSUN LINTUNGPAKU DESA KARANGPAWITAN KECAMATAN KAWALI KABUPATEN CIAMIS
}

\section{THE STRATEGY OF DEVOLOPING THE TOFU CAHAYA AGROINDUSTRY IN LINTUNGPAKU HAMLET, KARANGPAWITAN VILLAGE,KAWALI DISTRICT, CIAMIS REGENCY}

\author{
ADE FITRI A'SYAROH ${ }^{1 *}$, DINI ROCHDIANI ${ }^{2}$, BUDI SETIA ${ }^{1}$ \\ ${ }^{1}$ Fakuktas Pertanian Universitas Galuh \\ ${ }^{2}$ Fakultas Pertanian Universitas Padjajaran \\ E-mail : adefitriasyaroh@gmail.com
}

\begin{abstract}
ABSTRAK
Penelitian ini bertujuan untuk mengetahui : 1) Faktor-faktor yang menjadi kekuatan dan kelemahan dalam pengembangan agroindustri Tahu Cahaya di Dususn Lintungpaku Desa Karangpawitan Kecamatan Kawali Kabupaten Ciamis. 2) Alternatif Strategi yang diterapkan dalam pengembangan agroindustri tahu pada perusahaan Tahu Cahaya di Dusun Lintungpaku Desa Karangpawitan Kecamatan Kawali Kabupaten Ciamis. Penelitian ini menggunakan metode studi kasus pada perusahaan Tahu Cahaya di Dusun Lintungpaku Desa Karangpawitan Kecamatan Kawali Kabupaten Ciamis. Responden pada penelitian ini adalah pemilik Tahu Cahaya yaitu Bapak Nurdin. Data yang digunakan adalah data primer dan sekunder. Analisis yang digunakan adalah analisis SWOT. Hasil penelitian ini menujukan bahwa :1) Faktor kekuatan (Strenghts), dalam pengembangan perusahaan tahu Cahaya yaitu memiliki lokasi yang strategis yang mudah dijangkau oleh konsumen, pengalaman perusahaan, kapasitas produksi, ketersediaan bahan baku, kemampuan mengakses modal, dan memiliki rasa tahu yang enak, tidak mudah hancur dan tidak berbau asam. Sedangkan yang menjadi faktor kelemahan (weaknesses) diantaranya yaitu keterbatasan sumberdaya/ kapabilitas perusahaan, pembuangan limbah, pemasaran masih terbatas, belum adanya riset pesaing, jumlah alat transfortasi milik sendiri sedikit, dan ketergantungan bahan baku.2) Alternatif strategi yang tepat untuk diterapkan dalam pengembangan usaha agroindustri tahu cahaya yaitu dengan menggunakan strategi SO. setelah menggandengkan kekuatan dengan peluang dan strategi SO (Strenght-Opportunity), maka diperoleh faktor yang harus dipertahankan untuk mampu mengambil peluang yang ada, yaitu mampu menjaga dan meningkatkan mutu produk dan memperluas pasar.
\end{abstract}

Kata Kunci : Agroindustri, Kekuatan, Kelemahan.

\begin{abstract}
This study aims to determine : 1) the factor which are the strenght and weaknesses in the development of the Cahaya Tofu Agroindustri in Lintungpaku Hamlet, Karangpawitan Village, Kawali District, Ciamis Regency. 2) alternative strategies applied in the development of tofu agro-industry in Cahaya Tofu companies in Lintungpaku Hamlet, Karangpawitan Village, Kawali District, Ciamis Regency.This study uses the case study methode, at the company of Tofu Cahaya in Lintungpaku Hamlet, Karangpawitan Village, Kawali District, Ciamis Regency. Respondents in this study were the owner of Tofu, namely Mr.Nurdin. The data used are primary data and secondary data. The analysis used is a SWOT analysis.The result of this study indicate that : 1)The strength factor (Strengths), in the development of a tofu company, namely having strategic location that is easily accessible to consumers, company experience, production capacity, availability of raw materials, ability to access capital, and having a good taste, not easily destroyed, and does not smell sour. Meanwhile, the weaknesses factor include limited company resources/ capabilities, waste disposal, limited marketing, the absence of competitor research, the limited number of means of transportation, and dependence on raw material. 2).The right alternative strategy to be applied th the development of tofu agro-
\end{abstract}


industry is by using the SO stratetgy. After joning forces with opportunities and SO (StrenghtOpportunity) strategies, it is necessary to maintain the factor that must be maintained in order to be able to take existing opportunities, namely being able to maintain and improve product quality and expand markets.

Keywords : Agroindustry, Internal, External

\section{PENDAHULUAN}

Dalam menghadapi era persaingan global tidak ada pilihan selain meningkatkan data saing nasional. Untuk mempertahankan dan meningkatkan daya saing nasional dalam rangka mewujudkan pembangunan yang berkesinambungan diperluakan suatu arah kebijakan pembangunan nasional dengan paradigma baru. Era reformasi yang berkembang sejak 1998 telah membawa banyak perubahan di berbagai bidang. Pemusatan kekuatan ekonomi nasional pada sekelompok tertentu telah surut seiring dengan terjadinya krisis ekonomi dan moneter. Paradigma pembangunan ekonomi yang semula lebih berorientasi pada pertumbuhan industri berskala besar telah bergeser kepada pembangunan ekonomi yang lebih ditekankan pada ekonomi kerakyatan. Perubahan paradigma tersebut telah berpengaruh terhadap proses pemulihan ekonomi yang tercermin dari beberapa indikator ekonomi (Kementrian Perindustrian, 2012).

Kedelai (Glycine max) merupakan komoditas yang telah lama dibudidayakan di Indonesia dalam prospek pengembangannya yang masih cerah. Hal ini memberikan isyarat bahwa kedelai mempunyai nilai ekonomi sosial yang sangat tinggi dan peranannya semakin strategis dalam tatanan kehidupan manusia. Kedelai merupakan komoditas pertanian yang sangat dibutuhkan indonesia baik sebagai bahan bahan makanan manusia, pakan ternak, bahan baku industri, maupun bahan penyegar. Kedelai mengandung kadar protein 40 persen dan lemakan 10-15 persen. Sampai saat ini kedelai masih merupakan bahan pangan sumber protein nabati yang paling murah sehingga tidak mengherankan bila total kebutuhan kedelai untuk pangan mencapai 95 persen dari total kebutuhan kedelai di Indonesia (Adisarwanto, 2008).

Tahu merupakan hasil olahan dari kedelai yang disenangi manusia karena harganya terjangkau dan juga merupakan salah satu jenis penganan murah dan enak. Tahu berasal dari Cina dan telah menjadi makanan populer masyarakat Indonesia. Kepopuleran tahu ini tidak terbatas karena rasanya yang enak, tetapi juga mudah 
dibuat dan dapat diolah menjadi berbagai bentuk masakan serta harganya relatif terjangkau. Tahu merupakan salahsatu makanan yang menyehatkan karena kandungan proteinnya tinggi dibandingkan dengan protein hewani (Siregar, 2014).

\section{METODE PENELITIAN}

\section{Jenis Penelitian}

Jenis penelitian yang digunakan adalah studi kasus pada industri tahu Cahaya di Dusun Lintungpaku Desa Karangpawitan Kecamatan Kawali Kabupaten Ciamis. Menurut Nazir (2010) studi kasus adalah penelitian tentang status subjek penelitian berkenaan dengan suatu fase spesifik atau khas dari keseluruhan personalitas. Subjek penelitian dapat saja individu, kelompok, lembaga maupun masyarakat.

\section{Operasionalisasi Variabel}

Variabel- variabel yang diteliti dalam penelitian meliputi:

1. Kedelai (Glysine $\max$ (L.) mer) adalah salah satu jenis kacangkacangan yang mengandung protein nabati yanng tinggi, sumber lemak, vitamin, dan mineral

2. Tahu adalah salah satu makanan tradisional yang populer, selain rasanya enak, harganya murah dan nilai gizinya pun tingi, bahan makan ini di olah dari kacang-kacangan khususnya kacang kedelai

3. Agroindustri adalah perusahaan yang mengolah bahan bahan yang berasal dari tanaman dan hewan .istilah agroindustri merujuk kepada suatu jenis industri yang bersifat pertanian. Agroindusti merupakan pusat rantai pertanian yang berperan penting dalam meningkatkan nilai tambah produk pertanian dipasar.

4. Strategi adalah pendekatan secara menyeluruh yang berkaitan dengan pelaksanaan ide/ gagasan, perencanaan, dan pelaksanaan suatu kegiatan dalam kurun waktu tertentu.

5. Pengembangan adalah suatu usaha untuk meningkatkan kemampuan konseptual, teoritis, teknis dan moral individu sesuai dengan kebutuhan pekerjaan atau jabatan melalui pendidikandan pelatihan.

6. Strategi pengembangan adalah langkah yang dirumuskan bersama berupa gagasan, perencanaan dan eksekusi dalam jangka waktu tertentu untuk mencapai perubahan kearah yang lebih baik.

7. Analisis SWOT dalam penelitian ini merupakan suatu analisis situasi 
yang mencakup kondisi internal dan eksternal dalam strategi pengembangan usaha tahu .

8. Faktor internal adalah adalah faktor faktor yang mempengaruhi strategi pengembangan usaha yang berasal dari dalam perusahaan.

9. Faktor eksternal adalah faktor-faktor yang mempengaruhi strategi pengembangan yang berasal dari luar perusahaan

10. Identifikasi faktor internal dan eksternal perencnaan strategi pengembangan agroindustri Tahu Cahaya ditekankan pada pertimbangan terhadap lingkungan internal dan eksternal dengan cara menganalisis faktor-faktor kekuatan dan kelemahan juga faktor peluang dan ancaman.

\section{Tehnik Pengumpulan Data}

Data yang digunakan dalam penelitian terdiri dari data primer dan data sekunder .Data Primer merupakan data yang diperoleh melalui wawancara secara langsung dengan responden untuk melihat dan mengamati situasi perusahaan. Data primer berupa faktor-faktor strategi internal dan eksternal diperoleh dengan wawancara menggunakan informan sebagai narasumber. Narasumber dalam pengambilan informasi tentang faktorfaktor internal dipilih dari pihak perusahaan. Tujuan dari pemilihan informan tersebut adalah dengan anggapan bahwa pihak perusahaan akan lebih mengetahui tentang faktor-faktor internal dan eksternal apa saja yang mempengaruhi perusahaan.

Data sekunder merupakan data yang diperoleh dan dikumpulkan dari instansi ataupihak lain (pihak eksternal). Dalam penelitian ini ada data sekunder diperoleh dari dinas perindustrian, Perdagangan dan Koperasi, jurnal, atau arsip yang dipublikasi maupun tidak dipublikasi secara umum,dan juga data- data yang mendukung atau yang berkaitan dengan masalah penelitian.

\section{Tehnik Penarikan Sampel}

Teknik penarikan sampel dilakukan secara sengaja (purposive sampling), dengan mewawancarai secara langsung pada pemilik agroindustri tahu Cahaya yaitu Bapak Nurdin. Menurut Sugiono (2009) purposive sampling adalah teknik pengambilan sampel sumber data dengan pertimbangan tertentu. Sampel dalam penelitian ini adalah pemilik agroindustri tahu Cahya ditentukan secara purposive untuk dijadikan responden. Dengan pertimbangan bahwa perusahaan tahu 
Cahaya memiliki kapasitas produksi paling besar dibanding yang lainnya.

\section{Rancangan Nalisis Data}

Untuk mengidentifikasi kekuatan dan kelemahan dari faktor internal serta peluang dan ancaman dari faktor eksternal dalam pengembangan agroindustri tahu Cahaya di Dusun Lintungpaku Desa Karangpawitan Kecamatan Kawali Kabupaten Ciamis akan digunakan analisis SWOT. Analisis SWOT adalah identifikasi berbagai faktor secara sistematis untuk merumuskan strategi perusahaan. Analisis ini didasarkan pada logika yang dapat memaksimalkan kekuatan (strengths) dan peluang (opportunies), namun secara bersamaam dapat meminimalkan kelamahan (weaknesses) dan ancaman (Threats). Proses pengembalian keputusan strategi berkaitan dengan pengembangan misi,tujuan,strategi dan kebijakan . Hal ini disebut dengan analisis situasi model yang paling popular untuk analisis ini adalah analisis SWOT (Rangkuti,2010).

Penentuan strategi pengembangan agroindustri tahu cahaya dengan menggunakan analisis SWOT, terlebih dahulu dihimpun data melalui daftar pertanyaan yang telah dirancang sesuai denhgan dimensi dan variabel untuk masing-masing faktor kekuatan, kelemahan, peluang dan ancaman. Setelah semua informasi yang berpengaruh terhadap kelangsungan kegiatan, tahap selanjutnya adalah memanfaatkan semua informasi tersebut dalam model kuantitatif perumusan strategi, dalam hal ini digunakan Matrix SWOT.

\section{Tempat dan Waktu Penelitian}

Penelitian ini dilaksanakan pada perusahaan agroindustri tahu Cahaya di Dusun Lintungpaku Desa Karangpawitan Kecamatan Kawali Kabupaten Ciamis. Adapun waktu penelitian dibagi dalam tahapan sebagai berikut :

1. Tahapan persiapan yaitu survei pendahuluan, penulisan Usulan Penelitian dan penyebaran kuesioner di rencanakan pada bulan Februari.

2. Tahapan pengumpulan data dari lapangan, yaitu pengumpulan data primer dan data sekunder direncanakan pada bulan Februari.

3. Tahapan pengolahan dan analisis data, penyusunan serta penulisan hasil penelitian direncanakan pada bulan Februari.

\section{HASIL DAN PEMBAHASAN}

Identitas Responden

Responden dalam penelitian ini adalah pemilik perusahaan tahu Cahaya yaitu Bapak Nurdin yang berada di Rt 05/ 
Rw 14 Dusun Lintungpaku Desa Karangpawitan Kecamatan Kawali Kabupaten Ciamis. Identitas Responden meliputi : umur, tingkat pendidikan, jumlah tanggungan keluarga, dan pengalaman berusaha.

a) Umur Responden

Umur adalah faktor yang mempengaruhi terhadap keberhasilan dalam melakukan suatu kegiatan usaha dan juga akan berpengaruh terhadap fisik dalam bekerja dan berfikir. Responden perajin tahu Cahaya Di Dusun Lintungpaku Desa Karangpawitan yaitu berumur 35 tahun. Dengan demikian responden berada pada umur produktif.

\section{b) Tingkat Pendidikan}

Tingkat pendidikan perannya cukup tinggi terhadap seseorang dalam melakukan kegiatan usaha, tapio pengalaman berusaha juga sangat tinggi perannya, karena tingkat pendidikan dan pengalaman berusaha dapat mempengaruhi seseorang dalam menerima dan melaksanakan inovasi baru. Pada umumnya tingkat pendidikan formal yang dicapai oleh perajin usaha agroindustri tahu Cahaya di Dusun Kiaralawang Desa Karangpawitan sebagian tamatan SMP. Tetapi responden penelitian ini yaitu Bapak Nurdin merupakan tamatan SMA.

\section{c) Pengalaman Berusaha Responden}

Pengalaman berusaha adalah faktor yang sangat penting untuk mencapai keberhasilan dalam melakukan usaha agroindustri, semakin lama pengalaman usaha maka akan semkin tinggi pula keterampilan yang dimiliki dalam melakukan proses produksi dan juga menghadapi permasalahanpermasalahan yang timbul dalam usaha. Pengalaman responden dalam penelitian ini yaitu telah berlangsung kurang lebih 8 tahun.

d) Tanggungan Keluarga Responden Responden yaitu pemilik usaha agroindustri tahu Cahaya di Dusun Lintungpaku Desa Karangpawitan Kecamatan Kawali Kabupaten Ciamis telah berkeluarga dengan jumlah tanggungan yang dimiliki yaitu 3 orang

\section{Strategi Pengembangan Agroindustri Tahu}

\section{a) IFAS (Internal Analysis Summary)}

Berdasarkan hasil penelitian pada responden perusahaan tahu Cahaya, maka diperoleh faktor-faktor 
internal kekuatan dan kelemahan yang mempengaruhi pengembangan usaha tahu Cahaya di Dusun Lintungpaku Desa Karangpawitan. Hasil analisis diperoleh bobot dikali nilai untuk faktor internal yaitu 2,90 Beberapa faktor internal yang berkaitan dengan pengembangan tahu Cahaya, yaitu :

a. Kekuatan

1. Pengalaman perusahaan

Pengalaman sangat berpengaruh terhadap kelangsungan usaha dan kemampuan perusahaan menghadapi permasalahan yang kerap muncul. Perusahaan Tahu Cahaya telah berpengalaman dalam berusaha karena telah berjalan selama 8 tahun ditambah dengan pengalaman pemilik perusahaan yang dulunya pernah dikenalkan dengan usaha tahu secara turun temurun.

\section{Kapasitas Produksi}

Kapasitas produksi menentukan pada tingkat pendapatan dibanding perusahaan sejenis. Perusahaan tahu cahaya memiliki kapasitas produksi terbesar dibanding perusahaan sejenis di Dusun Lintungpaku.

3. Ketersediaan bahan baku

Bahan baku utama untuk proses produksi tahu yaitu kedelai didapat dari penyuplai perorangan dengan sistem langsung antar ke tempat.

4. Kemampuan mengakses modal Modal merupakan awal dalam produksi tahu. Perusahaan mempunyai kemampuan untuk mengakses modal melalui pinjaman dan kemungkinan-kemungkinan lainnya.

5. Rasa Tahu yang enak, tidak mudah hancur dan tidak berbau asam

Rasa merupakan hal yang sangat penting bagi konsumen, maka perusahaan selalu mempertahankan dengan baik begitu pula dengan tekstur tahu yang tidak mudah hancur dan tidak berbau asam sangat di utamakan bagi perajin tahu Cahaya.

b. Kelemahan (Weaknesses)

1. Keterbatasan sumberdaya
perusahaan

Belum adanya peningkatan sumberdaya karyawan maupun perusahaan dalam penggunaan inovasi baru berupa teknologi modern

2. Pembuangan limbah perusahaan Limbah tahu merupakan bagian yang tidak dapat dipisahkan dari proses produksi tahun. Limbah tahu pad perusahaan tahu Cahaya telah 
lumayan tersturktur untuk pembuangannya sendiri, namun masih belum ada penampungan yang cukup luas untuk proses penampungan sebelum dialirkan ke sungai.

3. Pemasaran masih terbatas

Pemasaran mempunyai peranan penting dalam pengembangan usaha. Tahu Cahaya menjadi penyuplai ke 3 daerah yaitu pasar Kawali, pasar Lumbung, dan pasar Panawangan.

4. Belum adanya riset dan pesaing

Diadakannya riset dan pesaing memang penting, akan tetapi melaksanakan dengan baik harus dengan sistem dan tekhnik yang terstruktur dan dibutuhkan pendidikan, pelatihan kemampuan akademis yang lebih.

5. Jumlah alat transportasi masih sedikit

Alat transportasi berpengaruh terhadap perluasan pasar dalam pemasaran tahu cahaya.

\section{b) EFAS (Eksternal Analysis}

\section{Summary)}

Setelah faktor internal diketahui, selanjutnya adalah mengetahui faktorfaktor eksternal yang berpengaruh dalam strategi pengembangan agroindustri tahu Cahaya di Dusun Lintungpaku Desa
Karangpawitan Kecamatan Kawali Kabupaten Ciamis. Hasil analisis faktor eksternal diperoleh jumlah bobot dikali nilai 2,85 dan beberapa faktor eksternal yang berkaitan dengan pengembangan tahu, yaitu :

a. Peluang

1. Kemajuan teknologi produksi, komunikasi, dan informasi

Seiringnya berjalanya waktu, teknologi terus ditemukan sehingga dimungkinkan perusahaan dapat mengupdate teknologi produksi untuk hasil yang lebih maksimal didukung dengan sarana komunikasiberupa handphone dan media sosial sebagai sarana pendekatan dengan konsumen , kemudian untuk informasi kini semakin mudah didapat melalui jaringan internet dan sebagainya.

2. Permintaan pasar

Meningkatnya kesadaran masyarakat akan pentingnya mengonsumsi cukup protein sebagai penunjang peningkatan kualitas kesehatan dan terus bertambahnya jumlah penduduk diperkirakan permintaan pasar akan terus meningkat.

3. Memiliki pelanggan dan pembeli tetap 
Adanya pelanggan atau konsumen sebagai pembeli tetap, kerjasama ini harus terus dijaga untuk kelangsungan usaha tentunya dengan terus meningkatkan kualitas tahu dan kontinuitas tahu harus tetap terjaga

4. Penetapan lokasi perusahaan strategis

Penetapan lokasi perusahaan yang strategis yang didukung oleh akses menuju tempat usaha yang mudah dijangkau.

5. Tersediannya sarana transportasi yang baik meliputi jalan dan kendaraan

Sarana transportasi yang baik meliputi jalan dan kendaraan sangat mendukung terhadap proses produksi maupun pemasaran yang dilakukan perusahaan. Dalam ini akses jalan yang menuju perusahaan tahu Cahya sangat mudah di jangkau.

6. Daya beli masyarakat

Kesadaran akan pentingnya mengkonsumsi makanan yang memiliki nilai gizi dan terus meningkat pola fikir masyarakat akan meningkatkan keinginan daya beli masyarakat.

b. Ancaman (Threats)

1. Persaingan dengan industry sejenis

Semakin banyaknya pabrik tahu yang juga menghasilkan produk tahu terutama di dusun itu sendiri, hal ini berimbas pada persaingan pemasaran dan juga kualitas dan ketetapan penyuplai tahu.

2. Limbah yang berpengaruh terhadap lingkungan

Seiring berjalannya waktu, limbah perajin tahu yang tersebar di Dusun Kiaralawang Desa Karangpawitan jika tidak dikelola dengan baik dapat menjadi masalah dikemudian hari. Menurut responden, pemerintah melalui desa telah melakukan perundingan dengan para perajin tahu untuk merumuskan perihal pembuangan limbah tahu yaitu dengan membuat sebidang tanah luas untuk kemudian dijadikan kolam pengelolaan limbah sebelum nanti air nya dialirkan ke sungai.

3. Nilai tukar rupiah yang fluktuatif Naik turunnya nilai rupiah terhadap dolar menjadi berpengaruh pada bahan baku, karena perusahanan tahu mendapat bahan kedelai dari perorangan.

4. Lemahnya daya beli masyarakat 
Penurunan kemampuan daya beli masyarakat karena tidak stabilnya harga bahan pokok.

\section{Penentuan Posisi Perusahan}

Berdasarkan hasil perhitungan Diagram analisis SWOT, menunjukan bahwa posisi perusahaan tahu Cahaya di Dusun Lintungpaku Desa Karangpawitan Kecamatan Kawali Kabupaten Ciamis berada pada kuadran I, yaitu pada posisi strategi Kekuatan - Peluang (SO). Posisi ini memberikan indikasi bahwa ada peluang untuk dilaksanakan pengembangan usaha, serta memiliki posisi yang kuat untuk dikembangkan. Untuk lebih jelasnya dapat dilihat pada diagram analisis SWOT berikut.

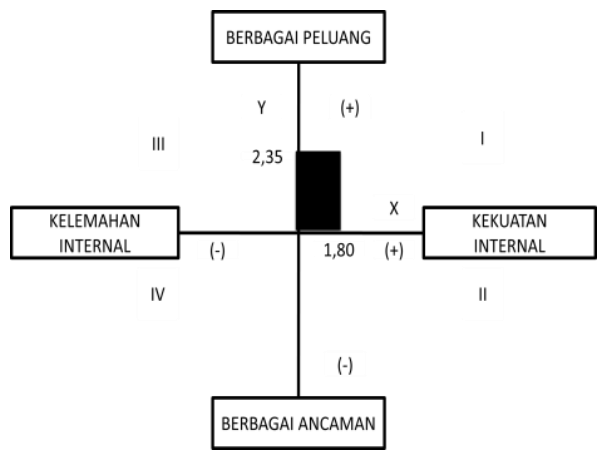

\section{Penentuan Strategi Perusahan}

Stetelah mengetahui semua informasi yang berpengaruh pada kegiatan strategi pengembangan agroindustri tahu Cahaya, tahap selanjutnya adalah memanfaatkan semua informasi tersebut dalam model kuantitatif perumusan strategi, dalam hal ini digunakan matrik
SWOT. Perusahaan Berada Pada Kuadran I maka penerapan strategi yang dapatb digunakan oleh Agroindustri Tahu Cahaya yaitu strategi SO. Strategi SO merupakan strategi yang dapat digunakan karena industri memiliki kekuatan dan peluang sehngga dapat memanfaatkan seluruh kekuatan untuk merebut dan memanfatkan peluang yang ada. Strategi SO yang telah dirumuskan yaitu :

1. Menjaga dan meningkatkan mutu produk

Untuk menjaga kepercayaan pelanggan yang ada, perusahaan perlu mempertahankan dan meningkatkan kualitas produk ataupun pelayanan agar terciptanya kepercayaan yang berkelanjutan.

2. Memperluas pasar

Untuk meningkatkan pendapatan perusahaan agar lebih berkembang, maka perluasan jaringan pemasaran harus dilakukan .

3. Mempertahankan rasa tahu yang enak, tidak mudah hancur, dan tidak berbau asam

Untuk menjaga agar pelanggan yang ada tetap setia terhadap produk, maka perlu dipertahankan rasa dan tekstur tahu yang tidak mudah hancur dan tidak berbau 
asam sekaligus meningkatkan kualitas mutu produk .

\section{KESIMPULAN DAN SARAN}

\section{Kesimpulan}

Berdasarkan hasil penelitian dan pembahasan maka dapat ditarik kesimpulan sebagai berikut :

1. Faktor kekuatan (Strenght), memiliki lokasi yang strategis yang mudah dijangkau oleh konsumen, pengalaman perusahaan, kapasitas produksi, ketersediaan bahan baku, kemampuan dalam mengakses modal, dan juga mempunyari rasa tahu yang enak, tidak mudah hancur dan tidak berbau asam.

Sedangkan yang menjadi faktor kelemahan (Weaknesses) yaitu keterbatasan sumberdaya/ kapabilitas perusahaan, pembuangan limbah, pemasran masih terbatas, belum adanya riset pesaing, jumlah alat transportasi milik sendiri sedikit, dan juga ketergantungan bahan baku kedelai.

2. Alternatif strategi yang tepat untuk diterapkan dalam pengembangan usaha agroindustri tahu cahaya yaitu dengan menggunakan strategi SO. setelah menggandengkan kekuatan dengan peluang dan strategi SO
(Strenght-Opportunity), maka diperoleh faktor yang harus dipertahankan untuk mampu mengambil peluang yang ada, yaitu mampu menjaga dan meningkatkan mutu produk dan memperluas pasar.

\section{Saran}

Berdasarkan penelitian yang telah diamati maka penulis mengemukakan saran sebagai berikut :

1. Kepada pemilik perusahaan Tahu Cahaya agar lebih meningkatkan produknya dengan cara meningkatkan kualitas dan mutu produk, dan memberikan logo agar masyarakat lebih mengenal Produk Tahu Cahaya.

2. Perusahaan hendaknya lebih meningkatkan promosi melalui periklanan, koran, dan media sosial lainya sehingga jangkauan promosi lebih luas . dengan jangkauan yang lebih luas maka akan bertambah banyak calon pelanggan yang mengenal Tahu Cahaya. Dan diharapkan mampu mempertahankan jangkauan calon konsumen yang belum tahu tentang perusahaan ini dan dapat memperluas target pasar. 


\section{DAFTAR PUSTAKA}

Adisarwanto, T.2008. Budidaya Kedelai

Tropika. Penebar Swadaya.

Jakarta.

Kementrian Perindustrian Republik Indonesia, 2012. Rencana Kinerja Tahunan Kementrian Pertanian Tahun 2013. Jakarta

Nazir, M.2011. Metode Penelitian. Ghalia indonesia. Cetakan 6. Bogor.
Rangkuti, F.2010. Analisis SWOT : Teknik Mmembedah Kasus Bisnis, Reorientasi, Konsep, Perencanaan

Strategis Untuk Menghadapi Abad

21. Cetakan 16. PT Gramedia Pusat Utama. Jakarta

Siregar, G.2014. Strategi Pengembangan Usaha Tahu Rumah Tangga. Jurnal Agrium Volume 19 No 1. Universitas Muhamadiyah Sumatra Utara. Sumatra Utara.

Sugiono. 2009. Metode Penelitian Kuantitatif Kualitatif dan R\&D. CV. ALFABETA. Bandung. 